\title{
Does Mobile Internet Addiction Affect Learning Achievement?
}

\author{
Chuan-Chun $\mathrm{Wu}, \mathrm{PhD} .{ }^{1}$, Ching-Kuo $\mathrm{Pu}^{2}$ \\ ${ }^{I}$ Department of Information Management/ I-Shou University, Taiwan R.O.C. \\ ${ }^{2}$ Department of Information Engineering / I-Shou University, Taiwan R.O.C.
}

\begin{abstract}
Today, the use of the Internet, especially mobile Internet, has become increasingly popular. With no restriction to using desktops, people can now easily gain access to the Internet and play online games with mobile phones or Wi-Fi tablets whenever and wherever they want. In light of this phenomenon, this study aimed to investigate the correlation between personality traits and mobile Internet addiction. The subjects were 16-18-year-old senior high school students who often used mobile Internet. The results of the study suggest that the duration of mobile Internet use is relevant to mobile Internet addiction; the longer the time or the more frequently students used mobile Internet, the more likely they were to become addicted to it. One more finding implied that there was a positive correlation between the students' learning attitude and their learning achievements and, furthermore, that there was no correlation between mobile Internet addiction and learning achievement. These findings serve as guidelines for school counsellors in assisting students with school studies.
\end{abstract}

Keywords: mobile Internet addiction (MIA), personality traits, learning achievement

\section{Introduction}

In addition to expanding our life circle and knowledge horizons, we hypothesize that the Internet will entice people who have certain personality traits or people who are easily influenced by the external environment to indulge themselves in the virtual cyber world. The easy accessibility of the Internet is the main reason why Internet addiction (IA) takes place (Anderson, 1999). Through online surveys it was found that approximately $6 \%$ of 18000 subjects were 'compulsive Internet users', and 4-6\% were regular Internet users. Furthermore, $29 \%$ of them suffered from emotional problems or could not steer their life back on track due to Internet use (Greenfield, 1999). Thus, it is assumed that there must be some factors that cause compulsive Internet users to undergo psychological and physical changes, and these changes affect their studies, jobs, physical and mental health, family relationships and relevant others (Atewell et al, 2003; Young, 2004).

According to the data provided by the Computer Center of Ministry of Education (MOE) in 2002, nearly 100\% of Taiwanese middle or senior high school students have used the Internet. Because of easy Internet accessibility, senior high school students in Taiwan are likely to become high-risk groups who may go on to suffer from IA. Although the Internet increases students' sources for learning and expands their vision, there is no doubt that many kinds of temptations and traps are hidden in the cyber world. At this important time in their school career when they are under great pressure because of their studies, the Internet can influence teenagers in their daily life, thoughts, studies, health and interpersonal relationships. We reflected on the function or satisfaction offered by computers that would entice students to become addicted to the Internet and what positive and negative effects the Internet would produce. We also considered the impact of the length of time students spent on the Internet and how this would affect their life, minds, studies, health, and interpersonal relationships. These questions drove us to investigate whether the amount of time students spent on the Internet was relevant to their IA. If students spent much time playing online games, their IA would become an important topic worthy of investigation. The purposes of this study are summarized as follows:

1) To determine the correlation between the economic conditions of senior high school students' families and their mobile IA (MIA) by examining their use of information technology (IT) equipment or mobile Internet.

2) To explore the correlation between high school students' mobile Internet use and their MIA.

3) To explore the correlation between high school students' MIA and their learning attitude.

4) To probe the correlation between high school students' MIA and their learning achievements.

5) To investigate the correlation between high school students' learning attitude and their learning achievements.

\subsection{Internet use}

\section{Literature review}

According to the Taiwan Network Information Center's (TWNIC) investigation at the end of July, 2014, the Internet population in Taiwan exceeded 17.64 million, and $77.66 \%$ of the over-12-year-old population (16.22 million) had experience of using Broadband Internet. Furthermore, users aged between 16 and 20 accounted for 95.57\% (1.55 million) of the teenage group, and their Internet usage time was increasing year by year (TWNIC, 
2014). This survey also found that participation in Internet communities was ranked highest at $64.31 \%$, while instant messaging was ranked second by $51.45 \%$ of users, and information acquisition was ranked third by $44.47 \%$ of users. These findings suggest that the Internet has become part of, and now shapes, our daily lives, while in turn our daily life is shaping the Internet (Castells, 1997).

\subsection{Mobile Internet addiction (MIA)}

Like an encyclopaedia, the Internet brings us much knowledge, but it also causes some problems. For example, some people feel they lack something in their daily life when they are not able to use the Internet on a daily basis; this is identified by psychoanalysts and psychiatrists as 'Internet addiction'. The first study of IA was conducted by Young (1996), who reported that $79.88 \%$ of 496 general Internet users were classified as Internet dependents. IA has increasingly been recognized as a potential problem since the introduction of the term by Goldberg in 1996 (Marshall, 1999). Like alcohol addiction or drug addiction, IA has symptoms such as tolerance, compulsive behaviour and relevant others (Goldberg, 1996). However, whether these addictions have a negative impact on the human body and daily life remains a controversial issue (Jennifer, 1997).

IA has generally been defined as an inability to control one's use of the Internet, resulting in psychological, social, family, school and work impairment (Young \& Rogers, 1998; Davis, 2001). However, the terminology or labels for IA are inconsistent in the literature. Some researchers recognize the phenomenon as Internet Addiction Disorder (IAD; Goldberg, 1996; Hur, 2006) whereas others prefer the widely used term Internet Addiction (IA; Nalwa \& Anand, 2003; Cao \& Su, 2006; Kima, et al., 2006; Ko, et al., 2007; Lam, et al., 2009; Yen, Ko, Chang, Cheng, \& Yen, 2009; Thomas \& Martin, 2010). IA has become the most widely accepted label for the range of general behaviours associated with an addiction to the Internet. Others have used Pathological Internet Use (PIU; Morahan-Martin \& Schumacher, 2000; Davis, 2001; Niemz, et al., 2005; Milani, et al., 2009); Internet addictive behaviour (Li \& Chung, 2006); compulsive Internet use (Meerkerk, Van Den Eijnden, Vermulst, \& Garretsen, 2009); or Internet dependency (Scherer, 1997).

The prevalence of IA has been examined among school student cohorts in many countries. Most research has reported a prevalence rate of $10 \%$ or less (Tsitsika et al., 2009; Seo, Kang \& Yom, 2009; Kaltiala-Heino, et al., 2004; Thomas and Martin, 2010; Zboralski et al., 2009), however, some studies have reported higher IA prevalence rates among students, for example, $10.7 \%$ in South Korea (Park, Kim, \& Cho, 2008), 10.8\% in China (Lam, et al., 2009) and $18.2 \%$ in Taiwan (Ko, et al., 2007).

There has never been a more efficient and direct input into our minds and nervous systems than the Internet. Currently, with the advent and proliferation of high-speed connections and mobile Internet portals such as smart phones, PDAs and many other portable devices, accessibility is even further enhanced. This study used the term Mobile Internet Addiction (MIA) to encompass all the various terms used in the literature.

\subsection{Personality traits}

Over the past 50 years, many psychiatrists have been trying to identify the relationship between man's intelligence and personality traits and to what degree one affected the other, but the results have not yet been finalized (e.g., Binet, Therman, Thorndike and Thurstone). David Wechsler (1950) claimed that intelligence was an overall presentation of man's personality traits, and asserted that intelligence was a combination of man's emotions and motives (interest and willpower for instance). Eysenck (1994), on the other hand, emphasized the need to distinguish between psychological and experimental approaches when measuring man's intelligence or personality traits. The psychological measurement allows us to comprehend the composition of man's ability and personality traits. Cattel (1971), for example, illustrated the association between man's ability (cognitive) and personality traits (non-cognitive). In contrast, experimental measurement exclusively relies on theories. Eysenck's psychology theory that builds a mode for man's personality through factor analysis has greatly challenged the way we use cognitive psychology to analyse man's intelligence. Eysenck asserted that the correlation between man's intelligence and personality traits could be identified through factor analysis. He concluded that, like a buffer that resisted man's stress and reduced the damage of man's disease, man's intelligence could provide something to help man grow up and adapt to the external environment.

\subsection{Learning achievement}

According to McClelland (1965), an authoritative psychologist of motivational studies from the USA, there is a significant correlation between students' learning achievements and their motives for learning. $\mathrm{He}$ claimed that motives were trainable and inspirable, and it was very important for an effective instructor to be able to trigger students' motivation to study so that an anticipated level of teaching effectiveness could be achieved.

In educational institutions in general, there are only a few artistic subjects that meet the students' psychological needs at the start of their learning. Most intellectual subjects rely on some positive incentives to motivate students' learning. Thus, to provide positive incentives, the teacher needs to design good teaching 
material before the class and choose appropriate teaching methods and activities so that students will be eager to learn and develop their motivation to learn.

Students' learning attitude is the motive for their learning achievement. Stein, et al. (2001) stated that the tool for measuring employees' competence in international companies is applicable to the assessment of the students' competence.

$$
\text { Competence }=(\text { Knowledge }+ \text { Skill })^{\text {Attitude }}
$$

Students' 'attitude' involves diligence, their practical nature, humility, active learning, peer learning, teacher-student interaction, peer relations, collaborative learning and relevant others. The common formula of measuring students' learning is: attendance + tests + the midterm examination + the final examination. However, these items cannot be fairly and genuinely used to measure students' learning achievements. The formula mentioned above could be modified as follows:

$$
\text { Learning achievement }=(\text { New knowledge }+ \text { Comprehension })^{\text {Attitude }} \text {. }
$$

\section{Methodology}

This study aimed to identify the correlation between mobile Internet use and MIA. Griffiths (1998) thought that IA was not purely a general material addiction; rather it was a technical addiction, a reliance based on human-machine interaction. Teenage senior high school students are eager to seek independence and self-identification, so tend to escape to the virtual world of the Internet when they cannot get satisfaction or encounter life problems (Suler, 2005). Morahan-Martin \& Schumacher's (2000) study found that addicts use the Internet to make new friends, seek spiritual support and chat with people who have similar interests more often than do non-addicts.

This study aimed to help us understand the impact of IA on senior high school students by investigating the correlations among their backgrounds, mobile Internet use, MIA, learning attitude and learning achievement. Statistical measurements were used during the investigation.

\subsection{Research framework}

This study mainly probed mobile Internet use of senior high school students, and their addiction based on their behavioural mode of using mobile Internet. Table 1 shows the research framework within which we explored the correlation among 'student backgrounds', 'personality traits', 'mobile Internet use', 'MIA', 'learning attitude' and 'learning achievement'.

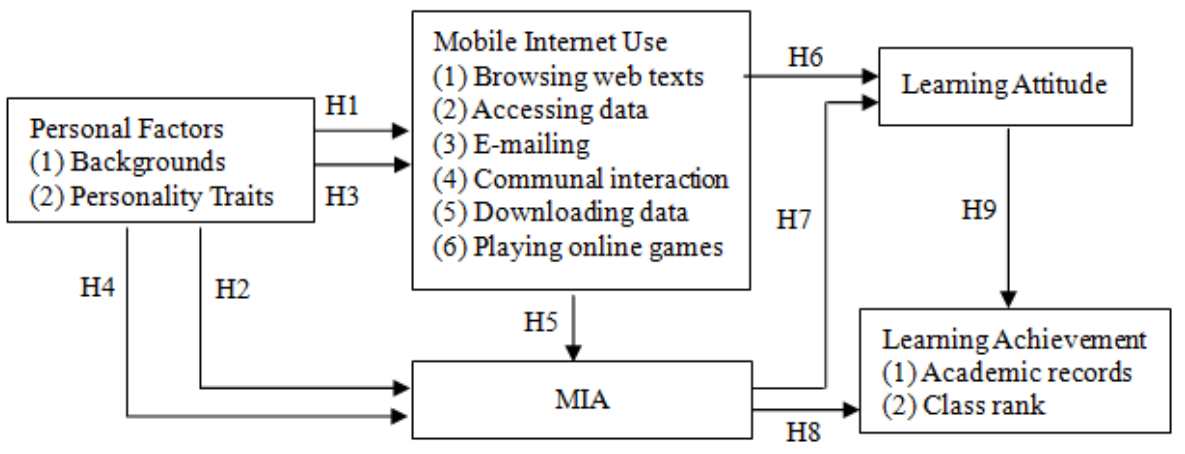

Figure1. Research framework

\subsection{Research hypotheses}

The study focused on the correlation between high school students and their MIA. The research variables included 'mobile network use', 'MIA', 'personality traits', 'learning attitude' and 'learning achievement'. The independent variables of effect included 'background information', 'mobile network use', 'MIA', 'extrovert personality traits', 'negative personality traits', 'neurotic personality traits', 'gentle personality traits', 'self-disciplined personality traits', 'clever personality traits', 'MIA', 'learning attitude', 'learning achievements', 'study habits and learning attitude', 'the desire for learning and learning attitude', and 'self-expectations and learning attitude'. The hypotheses that could be verified in this study are introduced as follows:

H1: High school students' mobile network use is related to their backgrounds.

H2: High school students' MIA is related to their backgrounds.

H3: High school students' personality traits are related to their mobile network use.

H4: High school students' personality traits are related to their MIA. 
H 4-1: High school students' MIA is related to their extrovert personality traits.

H4-2: High school students' MIA is related to their negative personality traits.

H4-3: High school students' MIA is related to their neurotic personality traits.

H4-4: High school students' MIA is related to their gentle personality traits.

H4-5: High school students' MIA is related to their self-discipline personality traits

H4-6: High school students' MIA is related to their clever personality traits

H5: High school students' mobile network use is related to their MIA.

H6: High school students' mobile network use is related to their learning attitude.

H7: High school students' MIA is related to their learning attitude.

H8: High school students' MIA is related to their learning achievement.

H9: High school students' learning attitude is related to their learning achievement.

H9-1: High school students' learning achievement is related to study habits of learning attitude.

H 9-2: High school students' learning achievement is related to the desire to learn about learning attitude.

H9-3: High school students' learning achievement is related to self-expectations of learning attitude.

\subsection{Research subjects and questionnaire}

Research subjects were students of all grades from Tainan A Senior High School. They were randomly selected and were asked to complete the questionnaire. The collected questionnaires were analysed using the statistical methods of reliability analysis, factor analysis and regression analysis.

The questionnaire was designed within the research framework for a specific purpose, and it was composed of six parts: the respondents' background data and personality traits; the activities performed on the mobile network; mobile network addiction, the Internet Addiction Scale (CIAS supports the progressive nature of IA and suggests that the more 'Yes' answers a respondent gives, the more likely s/he is at risk for IA; learning attitude which consists of three parts: study habits, learning desire and self-expectation, with the results showing that the higher the score a respondent achieves, the better learning attitude s/he has, and the lower the score, the poorer the attitude; finally, learning achievements that are ranked only based on the respondents' academic records, so the ranking prohibits obtaining the genuine results).

\section{Analysis of Research Results}

The respondents consisted of senior high school students of all grades. Three hundred copies of the questionnaire were randomly distributed to students and only 271 were used for statistical analysis after the incomplete and invalid ones were eliminated. The retrieval rate was $90.33 \%$.

\subsection{Reliability analysis}

The questionnaires were analysed respectively in terms of personality traits, activities performed on the mobile network, mobile network addiction and learning attitude. Details of the analyses are introduced as follows:

(1) As shown in Table 1, personality traits include six dimensions: extrovert, negative, neurotic, gentle, self-disciplined and clever. A 5-point rating scale was applied to the questionnaire design and the respondents selected answers based on their own situations. The results were highly consistent, which indicates that the research was suited for senior high school students.

Table1. Reliability analysis of personality traits

\begin{tabular}{|l|l|l|l|}
\hline Variables & Number & Cronbach's Alpha & Remark \\
\hline Extrovert & 4 & 0.748 & $>0.7$ \\
\hline Negative & 5 & 0.778 & $>0.7$ \\
\hline Neurotic & 5 & 0.876 & $>0.7$ \\
\hline Gentle & 5 & 0.818 & $>0.7$ \\
\hline Self-disciplined & 6 & 0.725 & $>0.7$ \\
\hline Clever & 5 & 0.813 & $>0.7$ \\
\hline
\end{tabular}

(2) Table 2 shows students' mobile Internet use. The use was highly consistent which indicates that the questions posed in the questionnaire were suited to the investigation of students' mobile Internet use.

Table2. Reliability analysis of mobile Internet use

\begin{tabular}{|l|l|l|l|}
\hline Variables & Number & Cronbach's Alpha & Remark \\
\hline Browsing on mobile Internet & 7 & 0.937 & $>0.7$ \\
\hline E-mailing on mobile Internet & 3 & 0.862 & $>0.7$ \\
\hline Chatting on mobile Internet & 5 & 0.904 & $>0.7$ \\
\hline Downloading on mobile Internet & 4 & 0.854 & $>0.7$ \\
\hline Playing games on mobile Internet & 5 & 0.817 & $>0.7$ \\
\hline
\end{tabular}

(3) The questions posed on the questionnaire were used by the National Science Council (now Ministry of Science and Technology) and by Chen Shu-hui (2000) to investigate the phenomenon of the IA; it was 
therefore assumed that they were valid and reliable. The respondents were identified as mobile Internet addicts if their five answers met the standard. MIA is progressive so the respondents who gave more 'Yes' answers represent the higher risk group for IA.

(4) Table 3 shows the measurement of student learning attitude, divided into learning habits, learning desire and self-expectations. The higher a student's grades, the better attitude they had, and the lower the grades, the poorer their attitude.

Table3. Reliability analysis of learning attitude

\begin{tabular}{|l|l|l|c|}
\hline Variables & Number & Cronbach's Alpha & Remark \\
\hline Learning Habits & 13 & 0.931 & $>0.7$ \\
\hline Learning Desire & 9 & 0.845 & $>0.7$ \\
\hline Self-expectations & 16 & 0.929 & $>0.7$ \\
\hline
\end{tabular}

\subsection{Factor analysis}

This research adopted factor analysis to gain a construct validity of the measurement and used fewer dimensions to replace the original complicated ones to retrieve common factors from the variables. This research used the Kaiser-Meyer-Olkin (KMO) measure of sampling adequacy to analyse factors such as personality traits, mobile Internet use and learning attitude in the questionnaire. Only when the KMO value is above 0.7 and the square value of the Bartlett's Test of Sphericity is significant can the factor analysis be accepted. The results of factor analysis were as follows:

\section{(1) The factor analysis of personality traits}

The results of the questionnaire on personality traits showed the KMO value to be 0.859 which is larger than 0.7 and near 1 (Table 4), suggesting that the variables were highly correlated. The square value of Bartlett's Test of Sphericity was 6036.416 and the significance value reached a level of $p=0.000$, reflecting that the respondents were equally affected by the factors. These findings met the standards for factor analysis, so the research method was effective.

Table4. Factor analysis of personality traits with Kaiser-Meyer-Olkin and Bartlett's Test

\begin{tabular}{|l|l|l|}
\hline \multicolumn{2}{|l|}{ Kaiser-Meyer-Olkin (KMO) and Bartlett's Test } \\
\hline KMO Measure of Sampling Adequacy & 0.859 \\
\hline Bartlett's Test of Sphericity & Similar to Chi-Square Distribution & 6036.416 \\
\cline { 2 - 3 } & Significance & 0.000 \\
\hline
\end{tabular}

\section{(2) Factor analysis of MIA}

The results of the questionnaire on MIA show that the KMO value (0.932) was larger than 0.7 and near 1 (Table 5), suggesting that the variables were highly correlated. The square value of Bartlett's Test of Sphericity was 5296.504 and the significance value reached a level of $p=0.000$, indicating that the respondents were equally affected by some factors. These findings met the standard for factor analysis, so the research method was effective.

Table5. Factor analysis of mobile Internet addiction with Kaiser-Meyer-Olkin and Bartlett's Test

\begin{tabular}{|l|l|l|}
\hline \multicolumn{2}{|c|}{ Kaiser-Meyer-Olkin (KMO) and Bartlett's Test } \\
\hline KMO Measure of Sampling Adequacy & 0.932 \\
\hline Bartlett's Test of Sphericity & Similar to Chi-Square Distribution & 5296.504 \\
\cline { 2 - 3 } & Significance & 0.000 \\
\hline
\end{tabular}

\section{(3) Factor analysis of learning attitude}

Table 6 shows that the KMO in the learning attitude scale was larger than 0.7 and close to 1 . This finding supports a significant interaction among variables. The square of Bartlett's test of sphericity was 7093.895 and $p=0.000$, suggesting that common factors were shared by the tested participants. This finding met the standard for factor analysis, so the research method was effective.

Table 6 Factor analysis of learning attitude with Kaiser-Meyer-Olkin and Bartlett's Test

\begin{tabular}{|l|l|l|}
\hline \multicolumn{2}{|l|}{ Kaiser-Meyer-Olkin (KMO) and Bartlett's test } \\
\hline KMO measure of sampling adequacy & 0.940 \\
\hline Bartlett's test of sphericity & Square & 7093.895 \\
\cline { 2 - 3 } & Significance & 0.000 \\
\hline
\end{tabular}




\subsection{Regression Analysis}

In the questionnaire, research hypotheses were proposed based on dependent variables, independent variables and corresponding verification. After the questionnaires were collected and processed using regression analysis, Table 7 was designed to show the results of the hypotheses. In response to $\mathrm{H} 1$ and $\mathrm{H} 2$, the findings showed that students' backgrounds (e.g., the tool that is used to surf the net, the Internet fee, the economic situation of students' families and the place where they used mobile Internet) were not related to their mobile Internet use and their MIA. In reply to $\mathrm{H} 3$ and $\mathrm{H} 4$, the findings showed that students' personality traits were related to their mobile Internet use and their MIA. Different personality traits lead to different ways of using the Internet. For instance, one student preferred browsing websites while some students preferred using social networks and others preferred playing Internet games. In addition, the degree of MIA varied with the differing personality traits of the users. The extrovert and clever users were less addicted to mobile Internet. In response to H5, the findings indicated that the duration of mobile Internet use was associated with MIA, and the longer and more often students used mobile Internet, the greater the degree of MIA they had. In response to $\mathrm{H} 7$ and H8, the results showed that students' MIA was not connected to their learning attitude and learning achievements. The students who were addicted to mobile Internet did not necessarily have a good or bad learning attitude and did not absolutely have higher or lower achievements. Thus, students' MIA cannot be blamed for their learning attitude and learning achievements. In reply to H9, the results showed that students' learning attitude was related to their learning achievement. Students' learning achievement was determined by their learning attitude, so learning basically depends on attitude. Hard work is the main reason for students' higher or lower achievements, not their personality traits or their MIA.

In conclusion, students' duties are to study and cultivate correct reading habits. With teachers' guidance, students can perform well in their studies. Prohibiting students from using mobile Internet is inappropriate. A better way of reducing students' MIA is to inculcate a sense of self-respect, discipline and time control.

Table 7 Regression analysis

\begin{tabular}{|c|c|c|}
\hline Hypothesis & $\begin{array}{l}\text { Regression analysis } \\
\text { ANOVA test results }\end{array}$ & $\begin{array}{l}\text { Analysis of regression coefficient } \\
\text { (main significant factors) }\end{array}$ \\
\hline H1 & $\begin{array}{l}p=0.455>0.05 \\
\text { not significant }\end{array}$ & $\begin{array}{l}\text { High school students' mobile Internet use was unrelated to their } \\
\text { backgrounds. }\end{array}$ \\
\hline $\mathrm{H} 2$ & $\begin{array}{l}p=0.063>0.05 \\
\text { not significant }\end{array}$ & $\begin{array}{l}\text { Rates of mobile Internet }(p=0.005 \text {, standardized coefficient } \\
\text { Beta/SCB }-0.197) \text { use were related to high school students' MIA. }\end{array}$ \\
\hline H3 & $p=0.000<0.05 ;$ significant & $\begin{array}{l}\text { Personality }(p=0.000 / \mathrm{SCB} 0.284) \text { showed a positive relationship, } \\
\text { suggesting that high school students' personality traits were related to } \\
\text { their mobile Internet use. }\end{array}$ \\
\hline $\mathrm{H} 4$ & $\begin{array}{l}p=0.035<0.05 \\
\text { significant }\end{array}$ & $\begin{array}{l}\text { SCB }(0.128) \text { showed a positive relation, suggesting that high school } \\
\text { students' personality traits were related to their MIA. }\end{array}$ \\
\hline H4-1 & $\begin{array}{l}p=0.065>0.05 \\
\text { not significant }\end{array}$ & $\begin{array}{l}\text { MIA was unrelated to high school students' extrovert personality } \\
\text { traits. }\end{array}$ \\
\hline $\mathrm{H} 4-2$ & $\begin{array}{l}p=0.000<0.05 \\
\text { significant }\end{array}$ & $\begin{array}{l}\text { Petulance }(p=0.046, \mathrm{SCB}-0.131) \\
\text { Censoriousness petulance }(p=0.001 \text {, SCB }-0.245) \\
\text { High school students' MIA was related to their negative control of } \\
\text { personality traits; for those who had petulant and censorious } \\
\text { personality traits, the relationship was more significant. }\end{array}$ \\
\hline $\mathrm{H} 4-3$. & $p=0.000<0.05 ;$ significant & $\begin{array}{l}\text { Moody }(p=0.003 \text {, standardized coefficient }=-0.261) \\
\text { High school students' MIA was relevant to their neurotic personality } \\
\text { traits, especially for the students who were moody. }\end{array}$ \\
\hline $\mathrm{H} 4-4$ & $\begin{array}{l}p=0.00<0.05 \\
\text { significant }\end{array}$ & $\begin{array}{l}\text { Friendly }(p=0.039 \text {, standardized coefficient }=0.188) \\
\text { High school students' MIA was relevant to their gentle personality } \\
\text { traits, especially for students who were friendly. }\end{array}$ \\
\hline $\mathrm{H} 4-5$ & $\begin{array}{l}p=0.000<0.05 \\
\text { significant }\end{array}$ & $\begin{array}{l}\text { Organized }(p=0.042, \text { standardized coefficient }=0.152) \\
\text { Fun-loving }(p=0.000, \text { standardized coefficient }=-0.262)\end{array}$ \\
\hline H4-6 & $\begin{array}{l}p=0.153>0.05 \\
\text { not significant }\end{array}$ & $\begin{array}{l}\text { High school students' MIA was not relevant to their clever personality } \\
\text { trait. }\end{array}$ \\
\hline H5 & $\begin{array}{l}p=0.000<0.05 \\
\text { significant }\end{array}$ & $\begin{array}{l}\text { MIA }(p=0.000, \text { standardized coefficient }=0.387) \\
\text { High school students' MIA was relevant to their mobile Internet use. }\end{array}$ \\
\hline H6 & $\begin{array}{l}p=0.000<0.05 \\
\text { significant }\end{array}$ & $\begin{array}{l}\text { Learning attitude }(p=0.000 \text {, standardized coefficient }=0.313) \text { was } \\
\text { positively related. } \\
\text { High school students' mobile Internet use was relevant to their } \\
\text { learning attitude. }\end{array}$ \\
\hline H7: & $\begin{array}{l}p=0.517>0.05 \\
\text { not significant }\end{array}$ & High school students' MIA was not relevant to their learning attitude. \\
\hline $\mathrm{H} 8$ & $\begin{array}{l}p=0.471>0.05 \\
\text { not significant }\end{array}$ & $\begin{array}{l}\text { High school students' MIA was not relevant to their learning } \\
\text { achievements. }\end{array}$ \\
\hline H9 & $p=0.000<0.05 ;$ significant & $\begin{array}{l}\text { Learning achievement }(p=0.000 \text {, standardized coefficient } \beta=0.394) \\
\text { was positively correlated. }\end{array}$ \\
\hline
\end{tabular}




\begin{tabular}{|c|c|c|}
\hline & & $\begin{array}{l}\text { High school students' learning attitude and their learning } \\
\text { achievements were correlated. }\end{array}$ \\
\hline H9-1 & $p=0.000<0.05$, significant & $\begin{array}{l}\text { High school students' habitual learning attitude and their learning } \\
\text { achievements were correlated. }\end{array}$ \\
\hline H9-2 & $p=0.000<0.05 ;$ significant & $\begin{array}{l}\text { 'I think school learning is interesting' }(p=0.014 \text {, standardized } \\
\text { coefficient } \beta=0.211) \text {. } \\
\text { 'I think school courses will be very useful in the future' ( } p=0.025 \text {, } \\
\text { standardized coefficient } \beta=-0.182) \text {. } \\
\text { 'I believe studying hard makes me keep up with others' ( } p=0.019 \text {, } \\
\text { standardized coefficient } \beta=-0.168) \text {. } \\
\text { The three related variables above lead to a finding that high school } \\
\text { students' intention to learn and their learning achievements were } \\
\text { correlated. }\end{array}$ \\
\hline H9-3 & $p=0.000<0.05 ;$ significant. & $\begin{array}{l}\text { 'I care greatly about my grades, especially when my performance } \\
\text { drops below previous levels of achievement' }(p=0.022 \text {, standardized } \\
\text { coefficient } \beta=-0.193) \text {. } \\
\text { 'I want to be top of the class' ( } p=0.007 \text {, standardized coefficient } \beta= \\
-0.282) \text {. } \\
\text { High school students' learning achievements and their self-expectation } \\
\text { were correlated. }\end{array}$ \\
\hline
\end{tabular}

\subsection{Conclusion}

\section{Conclusions and Suggestions}

MIA is a new topic worthy of discussion following the emergence of IA. The technology of information industries improves quickly and mobile Internet has become a greatly relied upon informational tool. Thus, to achieve a high market share, telecommunication operators continue to organize promotional events with the aim of stimulating consumers to become mobile Internet users. The number of mobile Internet users increases annually. This service has grown to become a tool that people frequently use as a pastime and to communicate with; thus the level of IA also increases annually. This study mainly investigated the correlation between students' IA and their performance in school. The results of the study are expected to direct the attention of parents, school authorities and the public to the issue of MIA. The following conclusions are derived from the results of the study.

\section{(1) The correlation between personality traits and MIA}

Students are the main users of the Internet. Phubbers can be found everywhere because many people have smart phones. If the users have weak self-control, they can easily become addicted to mobile Internet. This study suggests that those people who have extrovert or clever personality traits are often unaffected, but those who have negative, neurotic, gentle or self-disciplined personality traits are more easily affected. Schools may assess students' Internet use by applying measurements or providing students with self-assessment methods to assist them in changing their mobile phone use habits.

\section{(2) The correlation between mobile Internet use and MIA}

According to the results of regression analysis, mobile Internet use and MIA are positively related. Regardless of whether we are e-mailing, browsing, downloading, social networking or playing online games, the Internet has become an integral part of our life. The more frequently we use the Internet, the greater the possibility of becoming mobile Internet addicts. This study shows that high school students' Internet use is quite frequent and their frequent use of Facebook or Line and other social networks supports the findings that they spend a long time on the Internet. Thus, students' IA is closely related to their Internet use, and a higher frequency of smart phone use leads to a greater degree of addiction.

\section{(3) The correlation between learning attitude and learning achievement}

The subjects of this study were high school students whose learning attitude directly affected their learning achievements during the course of their schooling. The results of regression analysis have shown that their learning attitude and their learning achievements were not only co-related but also affected each other. Students' high or low learning achievement depended on their learning attitude, and their learning attitude could be identified by examining their learning habits, learning desire and self-expectation. The results of this research showed that students who had good learning habits, a strong desire to learn and high self-expectation usually achieved at higher levels. Alternatively, those who had poor learning habits had a weak desire to learn, low self-expectation and achieved at lower levels. As a result, students' learning achievements depended on their learning attitude. 


\subsection{Suggestions}

The results of this research allow students, parents, teachers, school counsellors and the public to understand and emphasize MIA. Some counselling suggestions for students' MIA at school are provided below.

\section{(1) Communicating with students and not restricting their mobile Internet use}

Today, students' mobile Internet use tends to be functionally negative because they use it to play games, surf porn websites and watch porn videos. Senior high school students are in a mentally immature phase, so they have a strong curiosity about male-female relationships, sexual fantasy, emotional attachments and emphasize friendship more than kinship. For this reason, we need to show our concern and be aware that negative alienation may occur if we try to restrict and forbid their mobile Internet use. We need to study how to make effective communication with them through our concern, companionship and positive interactions so that the objective of counselling and treatment can be successfully achieved.

\section{(2) Understanding students' Internet use by designing some measurement of their mobile Internet use}

The symptoms of MIA include highly frequent use of mobile Internet and a loss of control over the length of time they spend using it. If students lack self-control, school teachers and parents should try to understand their problems and give them some instructions on how to make best use of the Internet for learning, rather than being enslaved by it. At school, some measurements can be used to examine students' Internet use and also allow students to perform self-examination. The results of these measurements can be discussed by teachers and students together, and the negative impact on mobile Internet student addicts can be avoided.

\section{(3) The impact of counselling strategies on mobile Internet addicts}

The school should understand if mobile Internet student addicts have some learning barriers and behavioural problems. There are varied impacts of MIA on students' studies, social relationships, time and health, so we need to employ some counselling strategies to help students understand their own problems, allow them to learn self-control and encourage them to reduce their mobile Internet use. We may study how to make students develop new interests, new hobbies and engage in wholesome entertainment so that they do not remain obsessed by mobile Internet and so only use the Internet as a tool for problem-solving and knowledge acquisition.

\section{Discussion}

This study demonstrated that MIA was not related to learning attitude or learning achievement. This finding transgressed common cognition. Perhaps this finding means that students with some personality traits (e.g., self-discipline or cleverness) will not develop MIA. This seems to imply that students who have a good learning attitude and high learning achievement will not have MIA. We therefore recommend that further studies should address the impact of personality traits on MIA.

\section{References}

[1]. Anderson, K. J., Internet Use among College Students: An Exploratory Study. Journal of American College Health, 50(1), 1999, 21 $-26$.

[2]. Greenfield, D. N., Virtual Addiction: Help for Net Heads, Cyber Freaks, and Those Who Love Them (Oakland, CA: New Harbinger Publications, 1999).

[3]. Atewell, P., Suazo-Garcia, B., \& Battle, J., Computers and Young Children Social Benefit or Social Problem?, Social Forces, 82(1), 2003, 277-296

[4]. Young, K. S., Internet Addiction: A New Clinical Phenomenon and Its Consequences., American Behavioral Scientist, 48(4), 2004, 402-415.

[5]. Taiwan Network Information Center (TWNIC), A Survey on Broadband Internet Usage in Taiwan (A Summary Report May 2014, http://www.twnic.net.tw/total/total_01.htm)

[6]. Castells, M., The information age: Economy, society, and culture, (vol. II: The Power of Identity, 2nd ed. Oxford: Wiley Blackwell, 1997).

[7]. Young, K. S., Internet Addictive: The Emergence of A New Clinical Disorder, Cyberpsychology and Behavior, 1(3), 1998, 237-244.

[8]. Marshall, W. L., Concepts of Abnormality Throughout History, In W. L. Marshall \& P. Firestone (Eds.), Abnormal psychology perspectives ( Toronto, Canada: Prentice-Hall, 1999) 1-22.

[9]. Goldberg, I., Internet Addictive Disorder (IAD) Diagnostic Criteria ( Retrieved from http://www.psycom.net/iadcriteria.html, 1996)

[10]. Jennifer R. F., Internet Addiction Disorder: Causes, Symptoms, and Consequences ( Retrieved from http://www. chem.vt..edu/, 2009)

[11]. Young, K., \& Rogers, R., The Relationship between Depression and Internet Addiction. Cyberpsychology and Behavior, 1(1), 1998, 25-28.

[12]. Davis, R. A., A Cognitive-behavioral Model of Pathological Internet Use. Computers in Human Behavior, 17(2), 2001, 187-195.

[13]. Hur, M., Demographic, Habitual, and Socioeconomic Determinants of Internet Addiction Disorder: An Empirical Study of Korean Teenagers. Cyberpsychology and Behavior, 9(5), 2006, 514-525.

[14]. Nalwa, K., \& Anand, A. P., Internet Addiction in Students: A Cause of Concern, Cyberpsychology and Behavior, 6(6), 2003, 653-656.

[15]. Cao, F. L., \& Su, L. Y., Internet Addiction among Chinese Adolescents: Prevalence and Psychological Features, Child: Care, Health and Development, 33(3), 2006, 275-281. 
[16]. Kima, K., Ryub, E., Chonb, M., Yeunb, E., Choic, S., Seod, J., \& Namd, B., Internet Addiction in Korean Adolescents and Its Relation to Depression and Suicidal Ideation: A Questionnaire Survey, International Journal of Nursing Studies, 43(2), 2006, $185-192$

[17]. Ko, C. H., Yen, J. Y., Yen, C. F., Lin, H. C., \& Yang, M. J., Factors Predictive for Incidence and Remission of Internet Addiction in Young Adolescents: a Prospective Study, Cyberpsychology and Behavior, 10(4), 2007, 545-551.

[18]. Lam, L. T., Peng, Z. W., Mai, J. C., \& Ing , J., Factors Associated with Internet Addiction among Adolescents. Cyberpsychology and Behavior, 12(5), 2009, 551-555.

[19]. Yen, C. F., Ko, C. H., Chang, Y. P., Cheng, C. P., \& Yen, J. Y., Multidimensional Discriminative Factors for Internet Addiction among Adolescents regarding Gender and Age. Psychiatry and Clinical Neurosciences, 63(3), 2009, $357-364$.

[20]. Thomas, N. J., \& Martin, F. H., Video-arcade Game, Computer Game and Internet Activities of Australian students: Participation Habits and Prevalence of Addiction, Australian Journal of Psychology, 62(2), 2010, 59-66.

[21]. Morahan-Martin, J., \& Schumacher, P., Incidence and Correlates of Pathological Internet Use among College Students, Computers in Human Behavior, 16(1), 2000, 13-29.

[22]. Niemz, K., Griffiths, M., \& Banyard, P., Prevalence of Pathological Internet Use among University Students and Correlations with Self-esteem, the General Health Questionnaire (GHQ), and Disinhibition. Cyberpsychology and Behavior, 8(6), 2005, 562-570.

[23]. Milani, L., Di Blasio, P., \& Osualdella, D., Quality of Interpersonal Relationships and Problematic Internet Use in Adolescence. Cyberpsychology and Behavior, 12(6), 2009, 681-684.

[24]. Li, S. M., \& Chung, T. M., Internet Function and Internet Addictive Behavior. Computers in Human Behavior, 22(6), 2006, 1067-1071.

[25]. Meerkerk, G. J., Van Den Eijnden, R., Vermulst, A. A., \& Garretsen, H. F. L., The Compulsive Internet Use Scale (CIUS): Some Psychometric Properties. Cyberpsychology and Behavior, 12(1), 2009, 1-6

[26]. Scherer, K., College Life on-line: Healthy and Unhealthy Internet Use, Journal of College Student Development, 38(6), 1997, 655-665.

[27]. Tsitsika, A., Critselis, E., Kormas, G., Filippopoulou, A., Tounissidou, D., Freskou, A., Kafetzis, D., Internet Use and Misuse: a Multivariate Regression Analysis of the Predictive Factors of Internet Use among Greek Adolescents. European Journal of Pediatrics, 168(6), 2009, 655-665.

[28]. Seo, M., Kang, H. S., \& Yom, Y. H., Internet Addiction and Interpersonal Problems in Korean adolescents, Cin-Computers Informatics Nursing, 27(4), 2009, 226-233.

[29]. Kaltiala-Heino, R., Lintonen, T., \& Rimpela, A., Internet Addiction? Potentially Problematic Use of The Internet in a Population of 12-18 Year-old Adolescents. Addiction Research and Theory, 12(1), 2004, 89-96.

[30]. Z Zoralski, K., Orzechowska, A., Talarowska, M., Darmosz, A., Janiak, A., Janiak, M., Gałecki, P., The Prevalence of Computer and Internet Addiction among Pupils. Postepy Hig Med Dosw (Online), 2(63), 2009, 8-12.

[31]. Park, S. K., Kim, J. Y., \& Cho, C. B., Prevalence of Internet and Correlation with Family Factors among South Korea Adolescents. Adolescence, 43(172), 2008, 895-900.

[32]. Binet. A., \& Simon, T., The Development of Intelligence in Children (Baltimore, Williams \& Wilkins, 1916, Reprinted 1973, New York: Arno Press; 1983, Salem, NH: Ayer Company).

[33]. David Wechsler, Cognitive, Conative and Non-intellective Intelligence, American Psychologist. 5, 1950, 78-83.

[34]. Eysenck, H. J., Creativity and Personality: Wood Association, Origence, and Psychoticism. Creativity Research Journal, 7(2), 1994, 209-216.

[35]. Cattell, R. B., Abilities: Their Structure, Growth and Action, (Boston, MA: Houghton Mifflin, 1971)

[36]. McClelland, D.C., Toward a Theory of Motive Acquisition, American Psychologist, 20, 1965, $321-333$.

[37]. Stein B. Jensen, et al., International Conference on Engineering Education, 2001 Oslo, Norway.

[38]. Griffiths, M., Internet Addiction: Does It Really Exist (Psychology and the Internet: Intrapersonal, interpersonal and transpersonal implications, 1998).

[39]. Suler, J., Adolescents in Cyberspace: The Good, the Bad, and the Ugly (In The Psychology of Cyberspace, www.rider.edu/suler/psycyber/basicfeat.html, 2005)

[40]. Chen, S. H., Assessing Psychopathology of Internet Addiction Disorder (2/2): Gender Differences of Internet Addiction in Taiwan, 2000 . 